\title{
Peroxisome proliferator-activated receptor $\gamma$ coactivator-1-dependent uncoupling protein-2 expression in pancreatic islets of rats: a novel pathway for neural control of insulin secretion
}

\author{
C. T. De Souza ${ }^{1}$, A. L. Gasparetti ${ }^{1}$, M. Pereira-da-Silva ${ }^{1}$, E. P. Araújo ${ }^{1}$, J. B. Carvalheira ${ }^{1}$, M. J. A. Saad ${ }^{1}$, \\ A. C. Boschero ${ }^{3}$, E. M. Carneiro ${ }^{3}$, L. A. Velloso ${ }^{1,2}$ \\ ${ }^{1}$ Department of Internal Medicine, State University of Campinas, UNICAMP, Campinas, SP, Brazil \\ 2 Departamento de Clínica Médica, FCM-UNICAMP, Campinas, SP, Brazil \\ ${ }^{3}$ Departments of Physiology and Biophysics, State University of Campinas, UNICAMP, Campinas, SP, Brazil
}

\section{Abstract}

Aims/hypothesis. Sympathetic inputs inhibit insulin secretion through $\alpha 2$-adrenergic receptors coupled with $\mathrm{Gi}$ protein. High adrenergic tonus generated by exposure of homeothermic animals to cold reduces insulin secretion. In this study we evaluate the participation of UCP-2 in cold-induced regulation of insulin secretion.

Methods. Static insulin secretion studies, western blotting and immunohistochemistry were used in this investigation.

Results. Exposure of rats to cold during 8 days promoted $60 \%(n=15, p<0.05)$ reduction of basal serum insulin levels concentration accompanied by reduction of the area under insulin curve during i.p. GTT $(50 \%$, $n=15, p<0.05$ ). Isolated islets from cold-exposed rats secreted $57 \%(n=6, p<0.05)$ less insulin following a glucose challenge. Previous sympathectomy, partially prevented the effect of cold exposure upon insulin secretion. Islets isolated from cold-exposed rats ex- pressed $51 \%(n=6, p<0.5)$ more UCP-2 than islets from control rats, while the inhibition of UCP-2 expression by antisense oligonucleotide treatment partially restored insulin secretion of islets obtained from cold-exposed rats. Cold exposure also induced an increase of $69 \%(n=6, p<0.05)$ in PGC-1 protein content in pancreatic islets. Inhibition of islet PGC-1 expression by antisense oligonucleotide abrogated cold-induced UCP-2 expression and partially restored insulin secretion in islets exposed to cold.

Conclusion/interpreatation. Our data indicate that sympathetic tonus generated by exposure of rats to cold induces the expression of PGC-1, which participates in the control of UCP-2 expression in pancreatic islets. Increased UCP-2 expression under these conditions could reduce the beta-cell ATP/ADP ratio and negatively regulate insulin secretion. [Diabetologia (2003) 46:1522-1531]

Keywords Insulin, uncoupling protein, PGC-1, islet, sympathetic.
The role played by neural inputs on beta-cell function has been a matter of intense investigation over the latest forty years [1]. The highest effect is believed to be exerted by parasympathetic fibres originated at the

Received: 20 May 2003 / Revised: 24 July 2003

Published online: 24 October 2003

(C) Springer-Verlag 2003

Corresponding author: Dr. L. A. Velloso, Departamento de Clínica Médica, FCM-UNICAMP, 13083-970 Campinas, SP, Brazil

E-mail: lavelloso@fcm.unicamp.br

Abbreviations: Ach, acetylcholine; DAG, diacylglycerol; NE, norepinephrine; PLC $\beta$, phospholipase $\beta$; PGC-1, PPAR $\gamma$ coactivator-1; UCP-2, uncoupling protein 2 . dorsal motor nucleus of the vagus [2] and by sympathetic fibres of the paravertebral sympathetic chain [3], both of which are under tight control of the hypothalmus [1].

Acetylcholine (Ach) mediates parasympathetic signals and acts upon pancreatic beta cells activating muscarinic M3 receptor subtype [4, 5], which in turn promotes phospholipase $\beta$ (PLC $\beta$ ) stimulation with subsequent diacylglycerol (DAG) and inositol 1,4,5 triphosphate (IP3) accumulation [6]. The net result is the elevation of cytosolic $\mathrm{Ca}^{2+}$ and increased insulin secretion. In contrast, norepinephrine (NE) released by sympathetic terminals stimulates beta-cell $\alpha 2$ adrenergic receptors that acting through $\mathrm{G}_{\mathrm{i}}$ or $\mathrm{G}_{0}$ pro- 
teins negatively modulate adenyl cyclase activity, reducing cAMP production and, ultimately, insulin secretion $[7,8,9]$.

Tight regulation of the ATP/ADP ratio in pancreatic beta cells is mostly under the control of metabolitedependent pathways, and exerts direct effects upon insulin secretion by controlling ATP-sensitive $\mathrm{K}^{+}$channels [10]. Recent findings show that uncoupling protein 2 (UCP-2) could participate in physiological control of insulin secretion by modulating mitochondria efficiency and thus the production of ATP [11]. Moreover, adenoviral over-expression of UCP-2 in pancreatic islets leads to impaired insulin secretion due to mechanisms proximal to $\mathrm{Ca}^{2+}$-dependent steps [12].

In thermogenically active organs such as brown adipose tissue and skeletal muscle, exposure to cold promotes the expression of a transcriptional coactivator named PPAR $\gamma$ coactivator-1 (PGC-1). The induction of PGC-1 increases the transcriptional activity of PPAR $\gamma$ and the thyroid hormone receptor in the uncoupling protein 1 (UCP-1) promoter. Since exposure of homoeothermic animals negatively modulates insulin secretion [13], which seems to be driven by high sympathetic tonus, we hypothesized that adrenergic inputs such as those generated by cold exposure might induce PGC-1 expression in rat pancreatic islets and thus modulate UCP-2 expression. The data obtained reveal a novel pathway that participates in neural control of insulin secretion.

\section{Materials and methods}

Antibodies, oligonucleotides, chemicals and buffers. Antibodies against UCP-2 (sc-6526), and PGC-1 (sc-5816) were from Santa Cruz Biotechnology (Santa Cruz, Calif., USA). ${ }^{125}$ I-Protein A Sepharose and ${ }^{125}$ I-insulin were from Amersham (Buckinghamshire, UK). Protein A Sepharose $6 \mathrm{MB}$ was from Pharmacia (Uppsala, Sweden). All the remaining chemicals used in the experiments were from Sigma (St. Louis, Mo., USA). Buffer A, used in immunoblotting experiments, consisted of $100 \mathrm{mmol} / 1$ Tris, $10 \mathrm{~g} / \mathrm{l} \mathrm{SDS}, 50 \mathrm{mmol} / \mathrm{l}$ Hepes ( $\mathrm{pH} 7.4$ ), $100 \mathrm{mmol} / \mathrm{l}$ sodium pyrophosphate, $100 \mathrm{mmol} / \mathrm{l}$ sodium fluoride, $10 \mathrm{mmol} / 1 \mathrm{EDTA}, 10 \mathrm{mmol} / \mathrm{l}$ sodium vanadate, $2.0 \mathrm{mmol} / \mathrm{l}$ PMSF and $0.1 \mathrm{mg} / \mathrm{ml}$ aprotinin. Krebs-bicarbonate buffer equilibrated with $95 \% \mathrm{O}_{2}: 5 \% \mathrm{CO}_{2}, \mathrm{pH} 7.4$ was used in islet isolation and contained either 2.8 or $16.7 \mathrm{mmol} / \mathrm{l}$ glucose. Insulin was determined by RIA and serum glucose by the glucose-oxidase method. Sense and antisense phosphorthioate-modified oligonucleotide specific for UCP-2 (sense, 5' TGT ATT GCA GAT CTC A 3' and antisense, 5' TGA GAT CTG CAA TAC A 3') and PGC-1 (sense, 5' TCA GGA GCT GGA TGG C 3' and antisense, 5' GCC ATC CAG CTC CTG A 3') were produced by Invitrogen (Carlsbad, Calif., USA). Each sequence was selected among three unrelated pairs of oligonucleotides on the basis of their ability to block UCP-2 or PGC-1 protein expression as evaluated by immunoblot of total protein extracts of isolated pancreatic islets utilizing specific anti-UCP-2 or antiPGC-1 antibodies, respectively. The selected sequences were analyzed (BLAST, NCBI) [14] for similarities with mRNA of other proteins and presented an intra-species $100 \%$ matching only for Rattus norvegicus UCP-2 and PGC-1, respectively.
Cold exposure protocols and characterization of the model. Male Wistar rats (Rattus norvegicus) (8 weeks old/200-260 g) obtained from the University of Campinas Central Animal Breeding Center were used in the experiments. The investigation followed the University guidelines for the use of animals in experimental studies and conforms to the Guide for the Care and Use of Laboratory Animals published by the US National Institutes of Health (NIH publication no. 85-23 revised 1996) and the protocol (protocol \#510-1) was approved by the State University of Campinas Ethical Committee. The animals were maintained on 12:12 artificial light-dark cycle and housed in individual cages. After an acclimatization period ( 3 days), the animals were randomly divided into two groups: cold-exposed $\left(4 \pm 1^{\circ} \mathrm{C}\right.$, up to 8 days $\left.-4^{\circ} \mathrm{C}\right)$ and thermoneutrally maintained animals $\left(23 \pm 1^{\circ} \mathrm{C}\right.$-also referred to as $\left.\mathrm{C}\right)$. The animals were allowed free access to standard rodent chow and water ad libitum. For experimental procedures rats were anaesthetized by intraperitoneal injection of sodium amobarbital $(15 \mathrm{mg} / \mathrm{kg}$ body weight), and the experiments were carried out after loss of corneal and pedal reflexes. Blood samples were obtained from rats fasted for $2 \mathrm{~h}$ for measurement of serum glucose and insulin.

Intraperitoneal glucose tolerance test (GTT). An intraperitoneal (i.p.) GTT was carried out at the end of the experimental period (8 days). After an overnight fast, the rats were anaesthetized as described above. After collection of an unchallenged sample (time 0$)$, a solution of $20 \%$ glucose $(2.0 \mathrm{~g} / \mathrm{kg}$ body weight) was administered into the peritoneal cavity. Blood samples were collected from the tail at 30, 60, 90 and 120 min for determination of glucose and insulin concentrations.

Insulin tolerance test (ITT). An intravenous (i.v.) ITT was carried out at the end of the experimental period ( 8 days). Food was withdrawn $6 \mathrm{~h}$ before the test and the rats were anaesthetized as described above. Insulin $(6.0 \mu \mathrm{g})$ was injected through the tail vein and blood samples were collected from the tail at $0,4,8,12$ and 16 min for serum glucose determination. The constant rate for glucose disappearance (Kitt) was calculated using the formula $0.693 / t_{1 / 2}$. The glucose $t_{1 / 2}$ was calculated from the slope of the least-square analysis of the plasma glucose concentrations during the linear decay phase [15].

Experimental protocols. Following the preliminary characterization of the model, rats were divided into six groups: thermoneutrally maintained $\left(23 \pm 1^{\circ} \mathrm{C} ; \mathrm{C}\right)$; thermoneutrally maintained and submitted to vagotomy; thermoneutrally maintained and submitted to sympathectomy $\left(23 \pm 1^{\circ} \mathrm{C} ; \mathrm{C}+\mathrm{S}\right)$; cold-exposed $\left(4^{\circ} \mathrm{C} \pm 1^{\circ} \mathrm{C} ; 4^{\circ} \mathrm{C}\right)$; cold-exposed and submited to vagotomy; and cold-exposed and submitted to sympathectomy $\left(4^{\circ} \mathrm{C} \pm 1^{\circ} \mathrm{C}\right.$; $\left.4^{\circ} \mathrm{C}+\mathrm{S}\right)$. Islets isolated from rats of each group were evaluated for basal and glucose-induced insulin secretion. Since previous vagotomy exerted no effect upon cold-induced modulation of insulin secretion we decided not to include vagotomy groups in further studies. Therafter, only groups $\mathrm{C}, 4^{\circ} \mathrm{C}, \mathrm{C}+\mathrm{S}$ and $4^{\circ} \mathrm{C}+\mathrm{S}$ were evaluated. Sympathectomy and vagotomy followed previously described techniques [16].

In vivo clonidine treatment. In some experiments sympathectomized rats were treated during 3 days with the $\alpha$ adrenergic agonist compound clonidine. For that, rats were allowed a 7 -day recovery period from the surgical procedure and then submitted to cold exposure protocol during 8 days. From day 5 of cold exposure on the rats were treated intraperitoneally with clonidine (Sigma St. Louis, Mo., USA) $(0.025 \mathrm{mg} / \mathrm{kg})$ at 7.00 a.m., 3.00 p.m. and 11.00 p.m. [17]. 
Islet isolation and static insulin secretion studies. Islets were isolated by hand picking following the collagenase digestion method $[5,18]$. To measure insulin secretion groups, five islets were pre-incubated for $45 \mathrm{~min}$ at $37^{\circ} \mathrm{C}$ in Krebs-bicarbonate buffer. The solution was then replaced by fresh buffer containing low $(2.8 \mathrm{mmol} / \mathrm{l})$ or supra-physiological $(16.7 \mathrm{mmol} / \mathrm{l})$ concentrations of glucose, and the islets were incubated for $1 \mathrm{~h}$ additionally. The insulin content of the medium at the end of the incubation period was determined by RIA. For static insulin secretion studies in islets treated with sense or antisense oligonucleotides, the following protocol was used; groups of five freshly isolated islets were initially incubated for $14 \mathrm{~h}$ at $37^{\circ} \mathrm{C}$, in RPMI $5.6 \mathrm{mmol} / \mathrm{l}$ glucose with no oligonucleotide or in the presence of either $2.0 \mathrm{nmol}$ sense or $2.0 \mathrm{nmol}$ antisense UCP-2 or PGC-1 oligonucleotide. The medium was then replaced by freshly prepared RPMI and islets were maintained for $1 \mathrm{~h}$ additionally under experimental conditions $(2.8 \mathrm{mmol} / \mathrm{l}$ glucose or $16.7 \mathrm{mmol} / \mathrm{l}$ glucose, with either no oligonucleotide addition or with sense or antisense UCP-2 or PGC-1 oligonucleotide). At the end of the incubation period, samples of the incubation medium were collected for hormone measurement. For measurement of the total insulin content, groups of 10 islets were sonicated and maintained overnight in $1 \mathrm{ml}$ of $75 \%$ ethanol/ $/ 2.2 \mathrm{~mol} / \mathrm{l} \mathrm{HCl}$. After extraction an aliquot was assayed for insulin content, expressed as ng/islet.

Immunohistochemistry. Pancreata from two control rats and two cold-exposed rats were examined to determine the expression and tissue distribution of UCP-2 and PGC-1. Hydrated, $5.0 \mu \mathrm{m}$ sections of paraformaldehyde-fixed, paraffin-embedded tissue were stained by the avidine-peroxidase method using primary antibodies against UCP-2 or PGC-1. Analysis and photo-documentation were done using an Olympus BX60 Microscope (Olympus America, Melville, N.Y., USA) [19].

Immunoblot and immunoprecipitation. For specific protein determination groups of 1500 freshly isolated islets from each experimental group were lysed in $0.3 \mathrm{ml}$ of boiling buffer $\mathrm{A}$ and insoluble material was removed by centrifugation during $20 \mathrm{~min}$ at $12000 \times \mathrm{g}$. Protein determination in the supernatants was determined by the Bradford method [20]. Samples containing $0.2 \mathrm{mg}$ total proteins were separated by SDS-PAGE, transferred to nitrocellulose membranes and blotted with specific antibodies. For immunoprecipitation followed by immunoblot, groups of 1500 pancreatic islets were exposed first to experimental conditions and then to cell lysis. Protein determination was carrried out and samples of $1.0 \mathrm{mg}$ total protein were incubated with primary antibody during $12 \mathrm{~h}$ at $4^{\circ} \mathrm{C}$. Precipitation of immunocomplexes, protein separation and transfer to nitrocellulose membranes was done as previously described [21]. Visualization of specific protein bands was carried out by incubating membranes with ${ }^{125}$ I-protein A followed by exposure to RX-films.

Statistical analysis. Specific protein bands present in the blots were quantified by densitometry (ScionCorp, Frederick, Md., USA). Mean values \pm SEM obtained from densitometric scans, and values for serum insulin and glucose during i.p. GTT, ITT and static secretion studies were compared utilizing TurkeyKramer test (ANOVA). A $p$ value of less than 0.05 was considered statistically significant.

\section{Results}

Metabolic characterization of rats exposed to cold. Several metabolic changes are induced by exposure of
Table 1. Effects of 8 days cold exposure upon metabolic parameters of rats

\begin{tabular}{lcc}
\hline Parameters & Control & $\mathrm{T}+4^{\circ} \mathrm{C}$ \\
\hline Food Intake $(\mathrm{g} / \mathrm{day})$ & $18.0 \pm 0.5$ & $34.0 \pm 1.0^{*}$ \\
Temperature $\left({ }^{\circ} \mathrm{C}\right)$ & $36.2 \pm 0.1$ & $36.0 \pm 0.2$ \\
Glucose $(\mathrm{mg} / \mathrm{dl})$ & $99.4 \pm 0.4$ & $97.2 \pm 0.3$ \\
Insulin $(\mathrm{ng} / \mathrm{ml})$ & $2.43 \pm 0.12$ & $1.49 \pm 0.23^{*}$ \\
Leptin $(\mathrm{pg} / \mathrm{ml})$ & $2335 \pm 267$ & $2003 \pm 234$ \\
TSH $(\mathrm{ng} / \mathrm{ml})$ & $13.45 \pm 1.43$ & $13.32 \pm 1.58$ \\
Corticosterone $(\mathrm{ng} / \mathrm{ml})$ & $102.5 \pm 15.5$ & $112.9 \pm 12.3$ \\
\hline
\end{tabular}

$* p<0.05$ vs. Control

homoeothermic animals to cold. As a rule, they present a discrete and transitory fall in body temperature, an increase in food consumption accompanied by weight loss during the initial days of cold exposure, and a discrete and transitory fall in blood glucose concentration, paralleled by a fall in insulin concentration. In this study similar characteristics were found in rats exposed to cold during a period of 8 days (Table 1). Concerning glucose metabolism and insulin secretion, we observed a fall in basal glucose levels at $2 \mathrm{~h}$ of cold exposure (Fig. 1a), which was promptly recovered and kept at similar levels of control throughout the remaining experimental period. In contrast, insulin concentration was lower in cold-exposed rats throughout the experimental period (Fig. 1b). During an i.p. GTT the concentration of blood glucose in control rats reached a maximum of about $270 \mathrm{mg} / \mathrm{dl}$ at $30 \mathrm{~min}$, and was higher than the glucose concentration of cold-exposed rats throughout the test (maximum glucose level in cold-exposed rats was about $128 \mathrm{mg} / \mathrm{dl}$ at $30 \mathrm{~min}$ ) (Fig. 1c). Although glucose clearance rates were higher in cold-exposed rats, the insulin concentration during the i.p. GTT were lower in these rats (Fig. 1d). A maximum $11.0 \mathrm{ng} / \mathrm{ml}$ blood insulin was reached at $30 \mathrm{~min}$ in control rats while at the same point in time it reached only about $4.0 \mathrm{ng} / \mathrm{ml}$ in cold-exposed rats. Higher responsiveness to insulin in cold-exposed rats was further shown during an i.v.ITT. Cold-exposed rats presented an about $45 \%$ increase in Kitt (Fig. 1e).

Sympathectomy partially restores glucose-induced insulin secretion in cold-exposed rats. To evaluate the role of neural signals upon cold-induced inhibition of insulin secretion rats were submitted to sympathectomy and vagotomy and static insulin secretion studies were carried out. Vagotomy did not produce an impact on insulin secretion from islets of cold-exposed rats and was therefore excluded from further studies. In contrast sympathectomy produced an increase in glucose-induced insulin secretion in islets isolated from cold-exposed rats (Fig. 2), in such a way that $4^{\circ} \mathrm{C}+\mathrm{S}$ group became statistically similar to $\mathrm{C}$. 
a

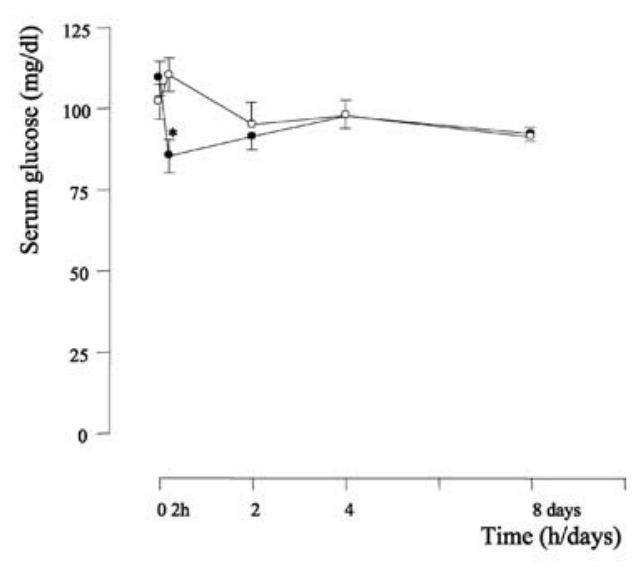

C

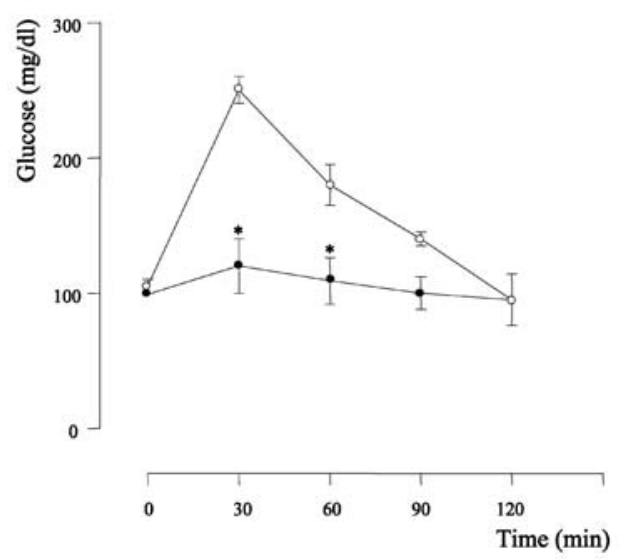

b
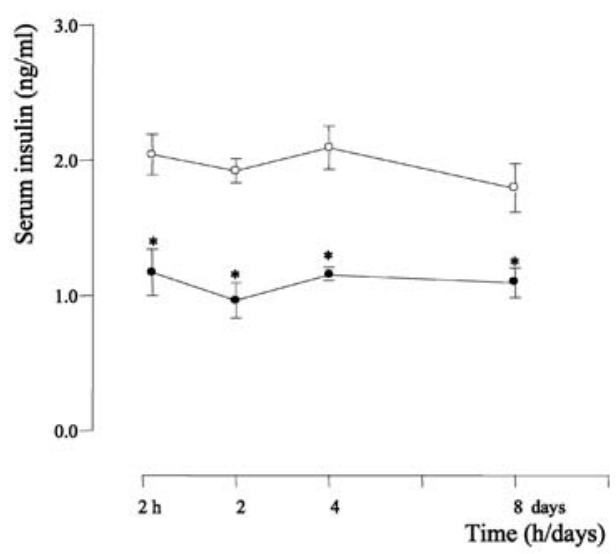

d

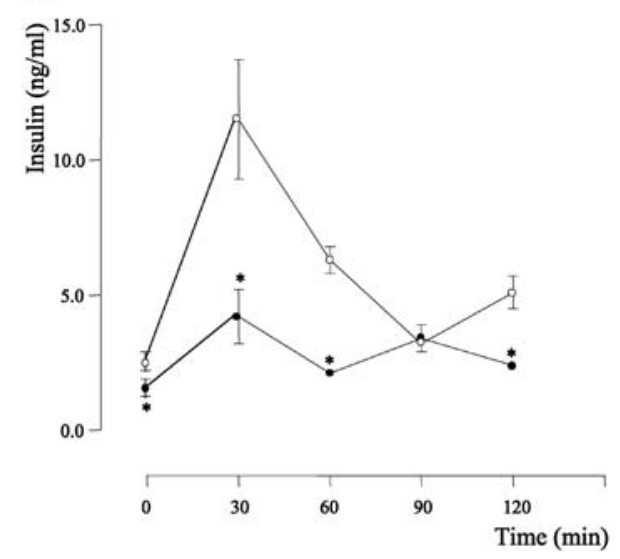

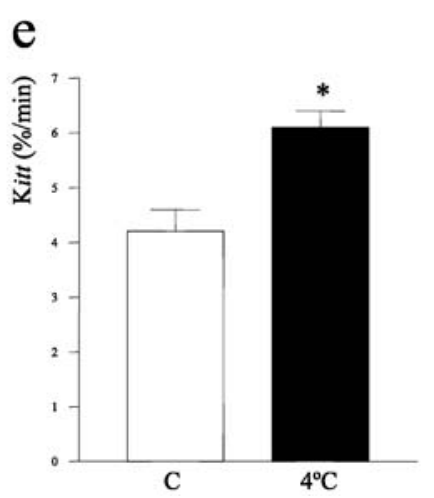

Fig. 1a-e. Metabolic characterization of rats exposed to cold. The variation of serum glucose (a) and insulin (b) concentrations were determined, in rats exposed to cold (filled circles) or maintained at thermoneutrality (open circles) during 8 days $(n=15)$. Serum glucose $(\mathbf{c})$ and insulin $(\mathbf{d})$ concentrations were determined during an i.p. GTT in rats exposed to cold (filled circles) or maintained at thermoneutrality (open circles) during 8 days $(n=15)$. (e) The constant rate for glucose disappearance (Kitt) was calculated and ITT was carried out in rats exposed to cold (filled bar) $\left(4^{\circ} \mathrm{C}\right)$ or maintained at thermoneutrality (open bar) (c) during 8 days $(n=6)$. In all experiments $* p<0.05$ vs control (C)
Cold exposure induces the expression of $P G C-1$ and $U C P-2$ in rat pancreatic islets. By immunoblot of protein extracts from isolated islets, low levels amounts of PGC-1 and UCP-2 were detected in rats from group C (Fig. 3b). By immunohistochemical analysis both UCP-2 (Fig. 3c) and PGC-1 (Fig. 3e) were detected as faint stains in a few scattered islet cells. Following cold exposure $\left(4^{\circ} \mathrm{C}\right)$ increases in UCP-2 $(51 \%$, $p<0.05)$ and PGC-1 $(59 \%, p<0.05)$ were observed in immunoblots (Fig. 3b) and could be more easily detected by immunohistochemistry (Figs. 3d,f). Previous sympathectomy in cold-exposed rats $\left(4^{\circ} \mathrm{C}+\mathrm{S}\right)$ led to a reduction in UCP-2 and PGC-1 expression (Fig. 3a,b). 

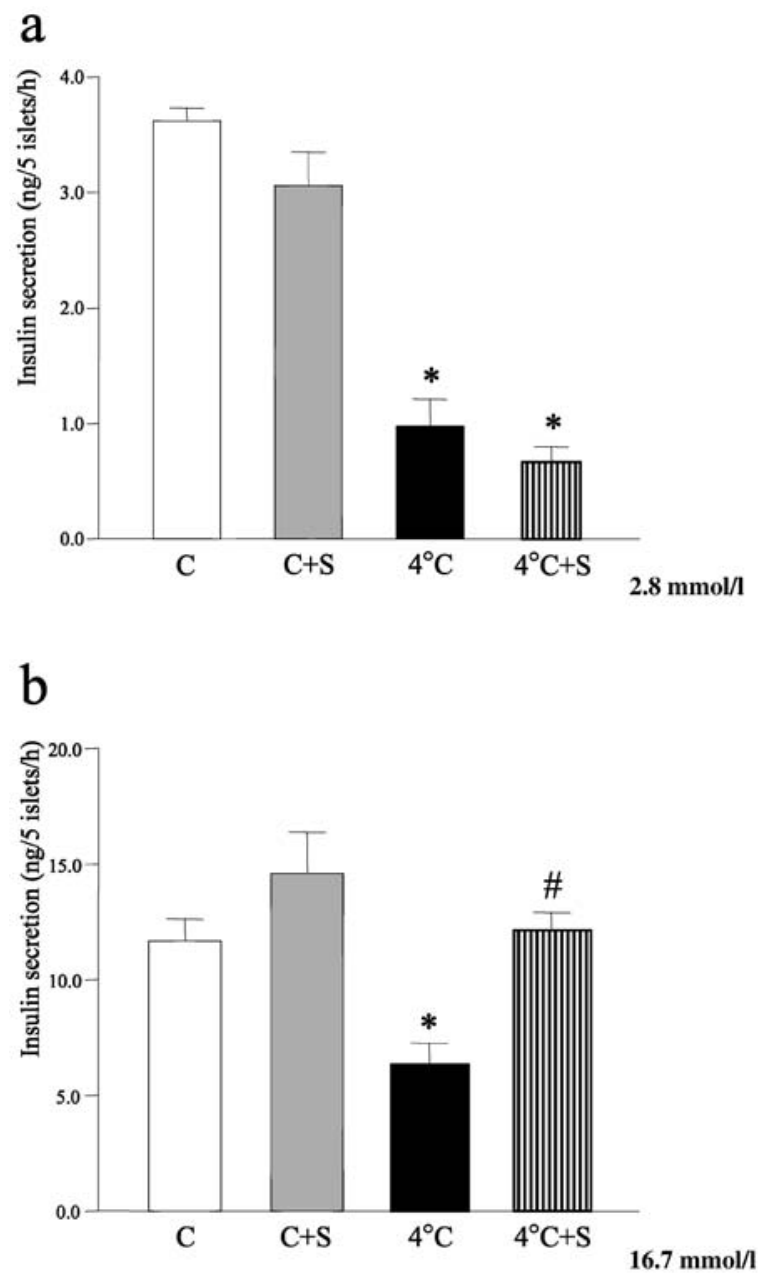

Fig. 2a, b. Static insulin secretion studies. Groups of five islets/well isolated from rats maintained at thermoneutrality and submitted $(\mathrm{C}+\mathrm{S})$ or not $(\mathrm{C})$ to sympathectomy, or isolated from rats exposed to cold and submitted $\left(4^{\circ} \mathrm{C}+\mathrm{S}\right)$ or not $\left(4^{\circ} \mathrm{C}\right)$ to sympathectomy, were incubated in the presence of $2.8 \mathrm{mmol} / \mathrm{l}$ glucose (a) or $16.7 \mathrm{mmol} / 1$ glucose (b) and evaluated for insulin secretion. In all experiments $n=6,{ }^{*} p<0.05$ vs. control (C) and $\# p<0.05$ vs. $4^{\circ} \mathrm{C}$

Inhibition of UCP-2 expression partially restores cold-induced inhibition of insulin secretion. Rats from each experimental group were treated with sense (S) or antisense (AS) UCP-2 phosphorthioate modified oligonucleotide and compared to animals treated with no oligonucleotide, for basal and glucose-stimulated static insulin secretion. Treatment with AS but not $\mathrm{S}$ oligonucleotide led to decreases of $34 \%(n=4$, NS) and $53 \%(n=4, p<0.05)$ in pancreatic islet UCP-2 protein expression in $\mathrm{C}$ and $4^{\circ} \mathrm{C}$ groups, respectively (Fig. 4a). S oligonucleotide treatment produced no changes in any of the evaluated conditions in the pattern of insulin secretion as compared to islets treated with no oligonucleotide. In contrast, inhibition of $\mathrm{UCP}-2$ expression in pancreatic islets from $4^{\circ} \mathrm{C}$ rats increased basal (Fig. 4c) and glucose-induced (Fig. 4g) static insulin secretion. Islet insulin content
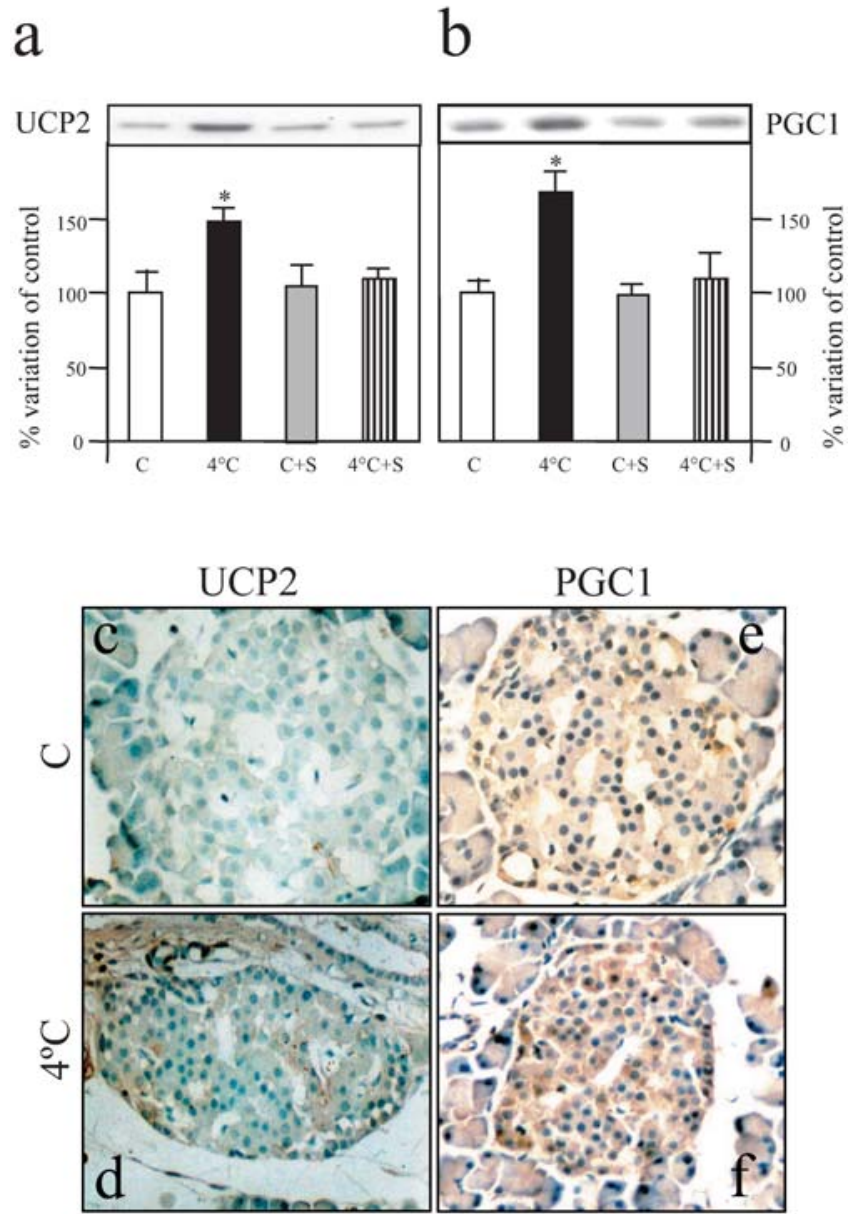

Fig. 3a-f. Expression of UCP-2 and PGC-1 in pancreatic islets. The protein amounts of UCP-2 (a) and PGC-1 (b) were determined in protein extracts obtained from islets of rats maintained at thermoneutrality and submitted $(\mathrm{C}+\mathrm{S})$ or not $(\mathrm{C})$ to sympathectomy, or islets of rats exposed to cold and submitted $\left(4^{\circ} \mathrm{C}+\mathrm{S}\right)$ or not $\left(4^{\circ} \mathrm{C}\right)$ to sympathectomy. $200 \mu \mathrm{g}$ of total protein extracts from each group were separated by SDSPAGE, transferred to nitrocellulose membranes and blotted with anti-UCP-2 (a), or anti-PGC-1 (b) antibodies. Tissue distribution of UCP-2 (c, d) and PGC-1 (e, f) were evaluated by immunohistochemistriy in paraffin-embedded sections of pancreata obtained from rats maintained in thermoneutrality (C), or exposed to cold $\left(4^{\circ} \mathrm{C}\right)$ during 8 days. In (a) and (b), $n=6$, $* p<0.05$ vs. control (C). From $\mathbf{c}$ to $\mathbf{f}, n=2$

Fig. 4a-i. Effect of UCP-2 protein expression blockade upon insulin secretion. The protein amounts of UCP-2 (a) were determined in protein extracts obtained from islets of rats maintained at thermoneutrality $(\mathrm{C})$ or exposed to cold $\left(4^{\circ} \mathrm{C}\right)$ and treated with sense (s) or antisense (as) UCP-2 phosphorthioate-modified oligonucleotide. $200 \mu \mathrm{g}$ of total protein extracts from each group were separated by SDS-PAGE, transferred to nitrocellulose membranes and blotted with anti-UCP-2 antibody. Groups of five islets/well isolated from rats maintained at thermoneutrality (C) $(\mathbf{b}, \mathbf{d}, \mathbf{f}, \mathbf{h})$ or exposed to cold $\left(4^{\circ} \mathrm{C}\right)(\mathbf{c}, \mathbf{e}, \mathbf{g}, \mathbf{i})$, were incubated in the presence of $2.8 \mathrm{mmol} / \mathrm{l}$ glucose $(\mathbf{b}-\mathbf{e})$ or $16.7 \mathrm{mmol} / \mathrm{l}$ glucose $(\mathbf{f}-\mathbf{I})$ and evaluated for static insulin secretion. Groups of islets were previously treated with sense (s), antisense (as) or no (wo) UCP-2 phosphorthioate-modified oligonucleotide. In all experiments $n=6, * p<0.05$ vs. wo 
a $\mathrm{UCP} 2 \mathrm{Cs}^{\mathrm{C}} \mathrm{C}^{\mathrm{as}} 4^{\circ \mathrm{CS}} 4^{\circ} \mathrm{C}^{\text {as }}$

$\mathrm{b}$

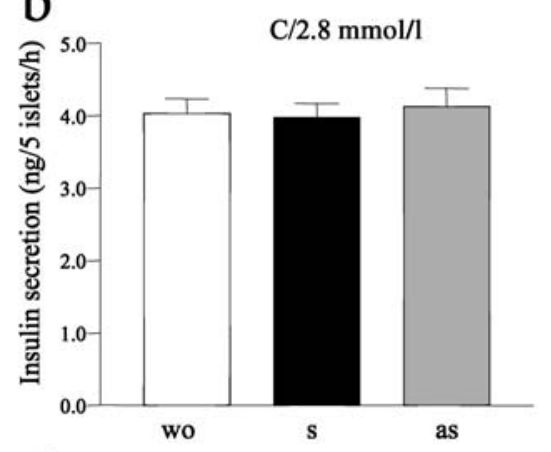

d

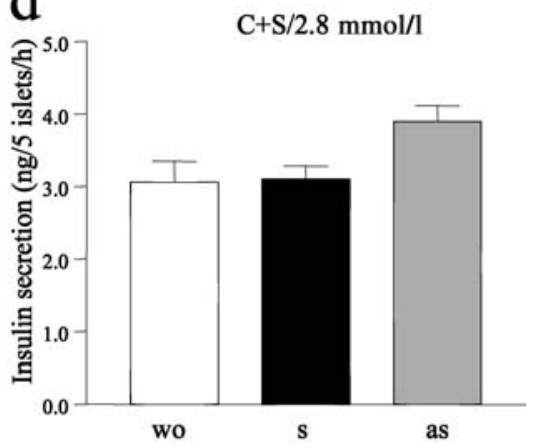

f

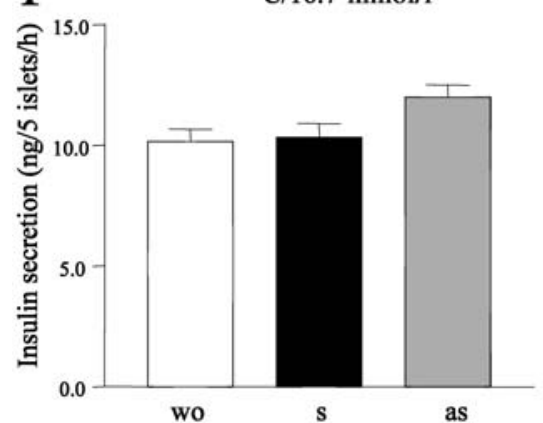

$\mathrm{h}$

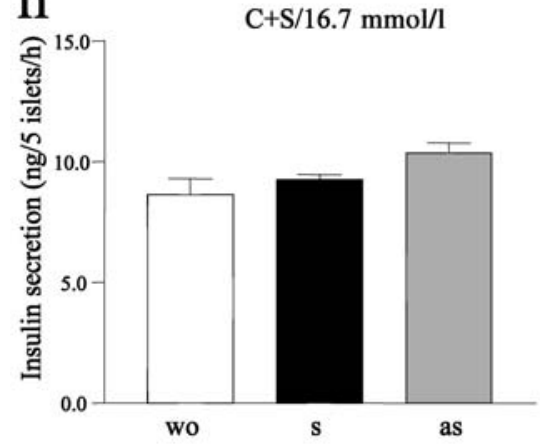

C

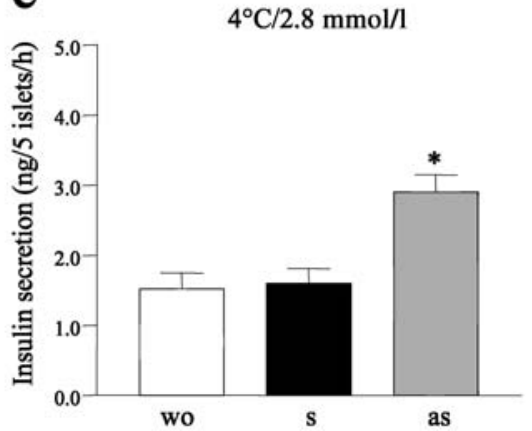

e

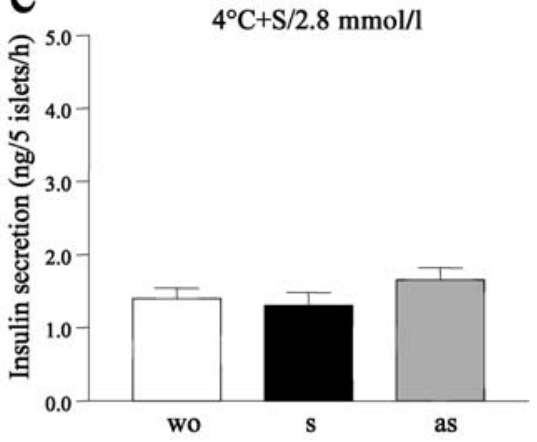

g $\quad 4^{\circ} \mathrm{C} / 16.7 \mathrm{mmol} / \mathrm{l}$
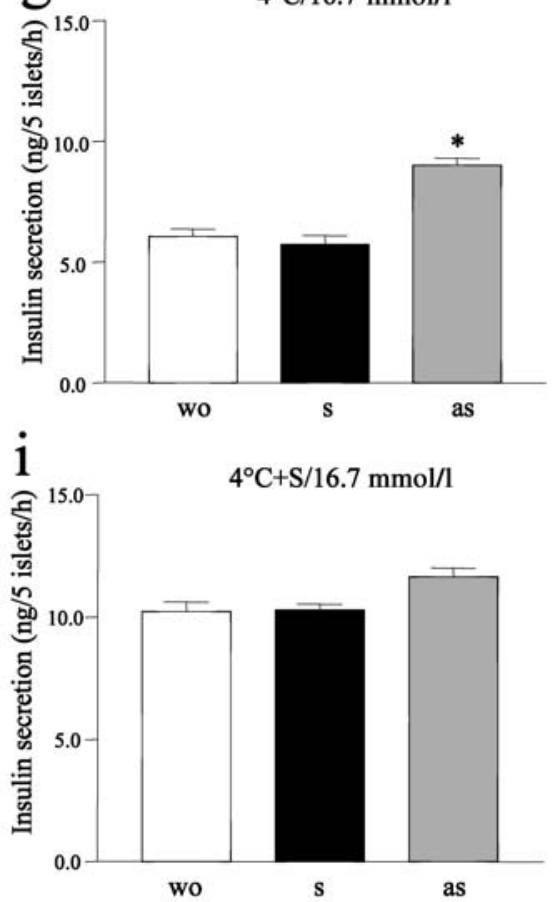
was neither modified by cold exposure $(58.1 \pm 6.9$ vs $51.6 \pm 4.5 \mathrm{ng} /$ islet, for $\mathrm{C}$ and $4^{\circ} \mathrm{C}$, respectively; $n=4$, NS), nor by UCP-2 protein expression blockade within each of the experimental groups (control + UCP-2 antisense oligonucleotide $=48.7 \pm 7.8 \mathrm{ng} /$ islet, $n=4$, NS vs $\mathrm{C}$; and $4^{\circ} \mathrm{C}+\mathrm{UCP}-2$ antisense oligonucleotide $=48.4 \pm 4.6 \mathrm{ng} /$ islet, $n=4$, NS vs $4^{\circ} \mathrm{C}$ ).

PGC-1 expression blockade abrogates cold-induced UCP-2 expression and partially restores cold-induced inhibition of insulin secretion. Rats of each experimental group were treated with sense $(S)$ or antisense (AS) PGC-1 phosphorthioate modified oligonucleotide and compared to rats treated with no oligonucleotide, for basal and glucose-stimulated static insulin secretion, and for UCP-2 protein expression. Treatment with AS but not S PGC-1 oligonucleotide led to decreases of $25 \%(n=4, \mathrm{NS})$ and $58 \%(n=4, p<0.05)$ in pancreatic islet PGC-1 protein expression in $\mathrm{C}$ and $4^{\circ} \mathrm{C}$ groups, respectively (Fig. 5a). Blockade of PGC-1 expression produced significant effects upon cold-induced UCP-2 expression, in such a way that cold-exposed, AS PGC-1-treated islets from $4^{\circ} \mathrm{C}$ rats expressed $40 \%(n=4, p<0.05)$ less UCP-2 than islets from $4{ }^{\circ} \mathrm{C}$ rats treated with no oligonucleotide (Fig. 5a). Similar to that observed in islets treated with AS UCP-2 oligonucleotide, in all of the herein evaluated conditions S PGC-1 oligonucleotide treatment produced no changes in the pattern of insulin secretion as compared to islets treated with no oligonucleotide. In contrast, inhibition of PGC-1 expression in pancreatic islets from $4^{\circ} \mathrm{C}$ rats increased basal (Fig. 5c) and glucose-induced (Fig. 5g) static insulin secretion. The blockade of PGC-1 protein expression did not modify islet insulin content within each of the experimental groups (control + PGC-1 antisense oligonucleotide $=46.3 \pm 6.7 \mathrm{ng} /$ islet, $n=4$, NS vs $\mathrm{C}$; and $4^{\circ} \mathrm{C}+\mathrm{PGC}-1$ antisense oligonucleotide $=44.4 \pm 5.8 \mathrm{ng} /$ islet, $n=4$, NS vs $\left.4^{\circ} \mathrm{C}\right)$.

Clonidine reestablishes pancreatic islet PGC-1 amounts in cold-exposed sympathectomized rats. Since most studies suggest that sympathetic stimulus inhibits insulin secretion through $\alpha$ adrenergic receptors, $4^{\circ} \mathrm{C}+\mathrm{S}$ rats were treated during 3 days with the $\alpha$ adrenergic compound clonidine following a previously described in vivo clonidine treatment protocol [17]. Clonidine treatment of cold-exposed sympathectomized rats reestablished pancreatic islet PGC-1 protein expression to amounts similar to those encountered in $4^{\circ} \mathrm{C}$ rats (Fig. 6).

\section{Discussion}

Fine-tuning of the insulin secretion rate is an important requirement for avoiding great variations in blood glucose concentration. Nutrients, hormones and neural signals are the main participants of this complex and integrated system [22]. Since early studies [23], noradrenergic stimulation of pancreatic islets is known to produce a net inhibitory effect upon insulin secretion. During the last three decades several studies have provided strong evidence that NE, acting through $\alpha 2$ adrenergic receptors expressed on the beta-cell surface, leads to reduced cAMP formation [24] and subsequently, to inhibition of the distal components of the insulin exocytotic machinery [9]. In addition, hyperpolarization of the pancreatic beta cells following adrenergic stimulus favours the opening of ATP-regulated $\mathrm{K}^{+}$channels [25]. The maintenance of opened ATP-regulated $\mathrm{K}^{+}$channels inhibits $\mathrm{Ca}^{2+}$ uptake and therefore inhibits insulin secretion. The molecular events that contribute for a sustained opening of the ATP-regulated $\mathrm{K}^{+}$channels in adrenergic stimulated beta cells are not yet fully understood.

In this study we provide evidence that high sympathetic tonus generated by exposure of homoeothermic animals to cold induces an increase of PGC-1 and UCP-2 protein amounts in the pancreatic islets, and that blockade of expression of either protein partially reverses cold-induced inhibition of insulin secretion. Since UCP-2 expression in mice pancreatic islet inhibits ATP production and through this mechanism interferes with insulin secretion [11], we hypothesized that the hyperpolarization of beta cells described in adrenergic-stimulated islets could be due to decreased ATP production as consequence of higher UCP-2 expression.

UCP-2 is a member of the mitochondrial uncoupling protein family $[26,27]$. Proteins that belong to this family are characterized by sub-cellular localization to the inner mitochondrial membrane where they uncouple biochemical respiration from oxidative phosphorylation by leaking protons into the mitochondrial matrix, which leads to a bypass of ATP synthase [28]. UCP-1 is the prototype of uncoupling proteins. It is predominantly expressed in brown adipose tissue

Fig. 5a-i. Effect of PGC-1 protein expression blockade upon UCP-2 expression and insulin secretion of pancreatic islets isolated from cold exposed rats. The protein amounts of PGC-1 and UCP-2 (a) were determined in protein extracts obtained from islets of rats maintained at thermoneutrality (C) or exposed to cold $\left(4^{\circ} \mathrm{C}\right)$ and treated with sense (s) or antisense (as) PGC-1 phosphorthioate-modified oligonucleotide. $200 \mu \mathrm{g}$ of total protein extracts from each group were separated by SDSPAGE, transferred to nitrocellulose membranes and blotted with anti-PGC-1 (a, upper blot) or anti-UCP-2 (a, lower blot) antibodies. Groups of five islets/well isolated from rats maintained at thermoneutrality $(\mathrm{C})(\mathbf{b}, \mathbf{d}, \mathbf{f}, \mathbf{h})$ or exposed to cold $\left(4^{\circ} \mathrm{C}\right)(\mathbf{c}, \mathbf{e}, \mathbf{g}, \mathbf{i})$, were incubated in the presence of $2.8 \mathrm{mmol} / \mathrm{l}$ glucose $(\mathbf{b}-\mathbf{e})$ or $16.7 \mathrm{mmol} / \mathrm{l}$ glucose $(\mathbf{f}-\mathbf{i})$ and evaluated for static insulin secretion. Groups of islets were previously treated with sense (s), antisense (as) or no (wo) PGC-1 phosphorthioate-modified oligonucleotide. In all experiments $n=6$, $* p<0.05$ vs. wo 
C. T. De Souza et al.: Peroxisome proliferator-activated receptor $\gamma$ coactivator-1-dependent

a

\begin{tabular}{|c|c|c|c|}
\hline & $\mathrm{Cs}^{\mathrm{s}}$ & $C^{25} a^{\circ C^{5}}$ & $4^{\circ C^{2}}$ \\
\hline PGC1 & $=$ & -0 & 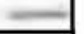 \\
\hline UCP2 & - & 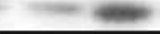 & $x^{2}$ \\
\hline
\end{tabular}
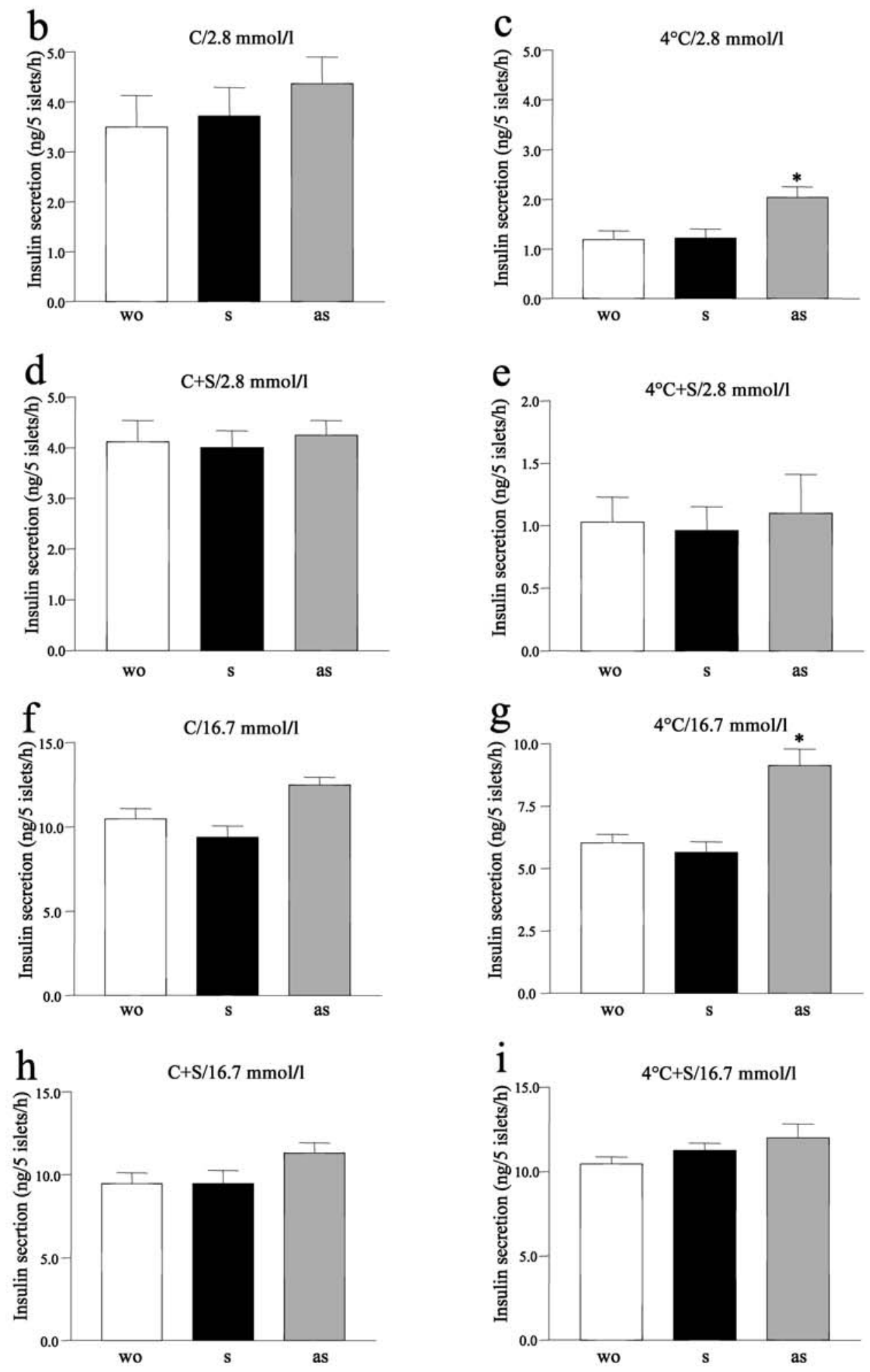


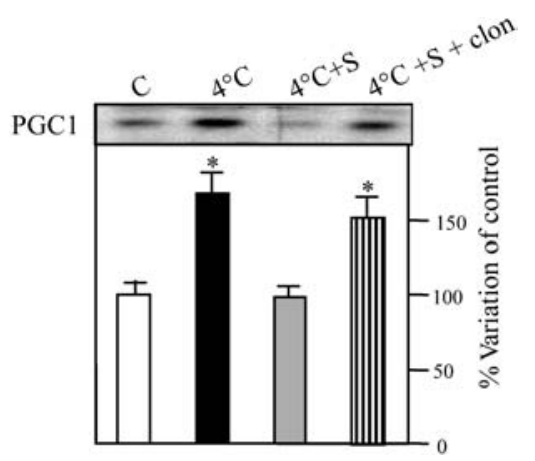

Fig. 6. Effect of in vivo clonidine treatment upon PGC-1 expression in pancreatic islets of cold-exposed, sympathectomized rats. The protein amounts of PGC-1 were determined in protein extracts obtained from islets of rats maintained at thermoneutrality $(\mathrm{C})$, exposed to cold $\left(4^{\circ} \mathrm{C}\right)$, exposed to cold and submitted to sympathectomy $\left(4^{\circ} \mathrm{C}+\mathrm{S}\right)$ and exposed to cold, submitted to sympathectomy and treated with colnidine ( $\left.4^{\circ} \mathrm{C}+\mathrm{S}+\mathrm{clon}\right) .200 \mu \mathrm{g}$ of total protein extracts from each group were separated by SDS-PAGE, transferred to nitrocellulose membranes and blotted with anti-PGC-1 antibody. $n=6$, $* p<0.05$ vs. control (C)

and participates in adaptive thermogenesis [29]. UCP-2 [30] and UCP-3 [31] have been identified more recently and are expressed in different tissues than UCP-1. UCP-2 is the homologue with the widest distribution and the only one reported to be expressed in pancreatic islets [32]. In a recent study, pathophysiological significance for UCP-2 expression in pancreatic islets was established in the obesity prone, leptin deficient ob/ob mouse [11]. According to this study obese mice express higher amounts of UCP-2 in the pancreatic islets than their respective controls. By intercrossing heterozygous ob/+ with $U C P-2+/-$ mice, double KO mice were generated (ob/ob, UCP-2 -/-). The abrogation of UCP-2 expression in ob/ob mice led to an improvement of first phase insulin secretion and whole body glucose metabolism [11]. It is of interest that exposure of pancreatic islets to leptin inhibits UCP-2 expression [33]. Thus, in ob/ob mice the lack of leptin could be the main factor responsible for increased islet UCP-2 expression. Another possible linkage between UCP-2 expression in pancreatic islets and anomalous insulin secretion refers to the fact that some fatty acids induce UCP expression and function, so it is possible that defective insulin secretion observed in some hyperlipidaemic states could be a consequence of UCP-2 expression [34, 35]. Therefore, in at least two examples of defective insulin secretion, a possible involvement of UCP-2 hyperexpression in pancreatic islets has been described. However, in none of these conditions the molecular mechanisms that lead to increased UCP-2 expression were shown.

PGC-1 is a nuclear receptor coactivator initially shown to be expressed in response to cold exposure in brown adipose tissue and skeletal muscle [36]. There is a difference from most nuclear receptor coactivators, PGC-1 activity seems to be regulated mostly by its tissue concentration [36]. The main physiological consequence of cold-induced PGC-1 expression in brown adipose tissue and skeletal muscle is the induction of UCP-1 protein expression and a subsequent increase in thermogenesis. The transcriptional control of the Ucp- 1 gene is regulated by cAMP levels contents [37], thyroid hormone [38] and PPAR $\gamma$ [36]. The same seems to be true for $U C P-2$ gene transcriptional control [39, 40, 41].

Our study shows that PGC-1 is expressed at low amounts in rat pancreatic islets. Exposure of rats to a cold environment or treatment of isolated islets with an $\alpha$ adrenergic agonist augment PGC- 1 expression, while sympathectomy prevents this effect. A straight correlation between PGC-1 and UCP-2 amounts was established and inhibition of PGC-1 expression abrogates both cold-induced UCP-2 hyperexpression and coldinduced defective insulin secretion. In fact, this study shows that partial blockade of PGC-1 or UCP-2 expression results in up to a $60 \%$ increase in basal and a $55 \%$ increase in glucose-induced insulin secretion. However, this increase was not sufficient to completely overcome the secretion defect induced by cold exposure. As reviewed elsewhere [42], reduction of cAMP accumulation in pancreatic islets is responsible for some, but not all, inhibitory effects of an adrenergic stimulus upon insulin secretion. By stimulating PGC-1 protein expression, adrenergic stimulus controls the amount of UCP-2 in pancreatic islets and therefore might modulate the ATP/ADP ratio. This mechanism, in parallel to classic dampening of cAMP signalling, transduces the inhibitory signal generated by adrenergic stimulus and thus regulates insulin secretion.

Acknowledgements. All studies were supported by grants from FAPESP.

\section{References}

1. Gilon P, Henquin JC (2001) Mechanisms and physiological significance of the cholinergic control of pancreatic betacell function. Endocr Rev 22:565-604

2. Berthoud HR, Fox EA, Powley TL (1990) Localization of vagal preganglionics that stimulate insulin and glucagon secretion. Am J Physiol 258:R160-R168

3. Ahren B, Karlsson S, Lindskog S (1990) Cholinergic regulation of the endocrine pancreas. Prog Brain Res 84:209-218

4. Henquin JC, Nenquin M (1988) The muscarinic receptor subtype in mouse pancreatic B-cells. FEBS Lett 236:89-92

5. Boschero AC, Szpak-Glasman M, Carneiro EM et al. (1995) Oxotremorine-m potentiation of glucose-induced insulin release from rat islets involves M3 muscarinic receptors. Am J Physiol 268:E336-E342

6. Sasaguri T, Hirata M, Itoh T, Koga T, Kuriyama H (1986) Guanine nucleotide binding protein involved in muscarinic responses in the pig coronary artery is insensitive to isletactivating protein. Biochem $\mathrm{J}$ 239:567-574

7. Chan SL, Perrett CW, Morgan NG (1997) Differential expression of alpha 2-adrenoceptor subtypes in purified rat pancreatic islet A- and B-cells. Cell Signal 9:71-78 
8. Lacey RJ, Chan SL, Cable HC et al. (1996) Expression of alpha 2- and beta-adrenoceptor subtypes in human islets of Langerhans. J Endocrinol 148:531-543

9. Sharp GW (1996) Mechanisms of inhibition of insulin release. Am J Physiol 271:C1781-C1799

10. Ashcroft FM, Gribble FM (1999) ATP-sensitive K+ channels and insulin secretion: their role in health and disease. Diabetologia 42:903-919

11. Zhang CY, Baffy G, Perret P et al. (2001) Uncoupling protein-2 negatively regulates insulin secretion and is a major link between obesity, beta cell dysfunction, and type 2 diabetes. Cell 105:745-755

12. Chan CB, MacDonald PE, Saleh MC, Johns DC, Marban E, Wheeler MB (1999) Overexpression of uncoupling protein 2 inhibits glucose-stimulated insulin secretion from rat islets. Diabetes 48:1482-1486

13. Vallerand AL, Frim J, Kavanagh MF (1988) Plasma glucose and insulin responses to oral and intravenous glucose in cold-exposed humans. J Appl Physiol 65:2395-2399

14. Altschul SF, Madden TL, Schaffer AA et al. (1997) Gapped BLAST and PSI-BLAST: a new generation of protein database search programs. Nucleic Acids Res 25:3389-3402

15. Bonora E, Manicardi V, Zavaroni I, Coscelli C, Butturini U (1987) Relationships between insulin secretion, insulin metabolism and insulin resistance in mild glucose intolerance. Diabet Metab 13:116-121

16. Larson GM, Sullivan HW, O’Dorisio T (1985) Surgical sympathectomy increases pancreatic polypeptide response to food. Surgery 98:236-242

17. Gurtu S, Shukla S, Mukerjee D (1994) Morphine, clonidine coadministration in subanalgesic doses: effective control of tonic pain. Neuroreport 5:715-717

18. Bjork E, Velloso LA, Kampe O, Karlsson FA (1994) GAD autoantibodies in IDDM, stiff-man syndrome, and autoimmune polyendocrine syndrome type I recognize different epitopes. Diabetes 43:161-165

19. Araujo EP, Amaral ME, Souza CT et al. (2002) Blockade of IRS1 in isolated rat pancreatic islets improves glucoseinduced insulin secretion. FEBS Lett 531:437-442

20. Bradford MM (1976) A rapid and sensitive method for the quantitation of microgram quantities of protein utilizing the principle of protein-dye binding. Anal Biochem 72:248254

21. Velloso LA, Folli F, Sun XJ, White MF, Saad MJ, Kahn CR (1996) Cross-talk between the insulin and angiotensin signaling systems. Proc Natl Acad Sci USA 93:12490-2495

22. Newgard CB (2002) While tinkering with the betacell...metabolic regulatory mechanisms and new therapeutic strategies: American Diabetes Association Lilly Lecture, 2001. Diabetes 51:3141-3150

23. Porte D Jr, Williams RH (1966) Inhibition of insulin release by norepinephrine in man. Science 152:1248-1250

24. Nakaki T, Nakadate T, Ishii K, Kato R (1981) Postsynaptic alpha-2 adrenergic receptors in isolated rat islets of Langerhans: inhibition of insulin release and cyclic $3^{\prime}: 5^{\prime}$-adenosine monophosphate accumulation. J Pharmacol Exp Ther 216:607-612

25. Nilsson T, Arkhammar P, Rorsman P, Berggren PO (1988) Inhibition of glucose-stimulated insulin release by alpha 2 -adrenoceptor activation is parallelled by both a repolarization and a reduction in cytoplasmic free $\mathrm{Ca} 2+$ concentration. J Biol Chem 263:1855-1860
26. Jezek P, Engstova H, Zackova M et al. (1998) Fatty acid cycling mechanism and mitochondrial uncoupling proteins. Biochim Biophys Acta 1365:319-327

27. Skulachev VP (1998) Uncoupling: new approaches to an old problem of bioenergetics. Biochim Biophys Acta 1363:100-124

28. Polonsky KS, Semenkovich CF (2001) The pancreatic beta cell heats up: UCP-2 and insulin secretion in diabetes. Cell 105:705-707

29. Klingenberg M, Huang SG (1999) Structure and function of the uncoupling protein from brown adipose tissue. Biochim Biophys Acta 1415:271-296

30. Fleury C, Neverova M, Collins S et al. (1997) Uncoupling protein-2: a novel gene linked to obesity and hyperinsulinemia. Nat Genet 15:269-272

31. Boss O, Samec S, Paoloni-Giacobino A et al. (1997) Uncoupling protein-3: a new member of the mitochondrial carrier family with tissue-specific expression. FEBS Lett 408:39-42

32. Zhou YT, Shimabukuro M, Koyama K et al. (1997) Induction by leptin of uncoupling protein-2 and enzymes of fatty acid oxidation. Proc Natl Acad Sci USA 94:6386-6390

33. Brown JE, Thomas S, Digby JE, Dunmore SJ (2002) Glucose induces and leptin decreases expression of uncoupling protein-2 mRNA in human islets. FEBS Lett 513: 189-192

34. Briaud I, Kelpe CL, Johnson LM, Tran PO, Poitout V (2002) Differential effects of hyperlipidemia on insulin secretion in islets of Langerhans from hyperglycemic versus normoglycemic rats. Diabetes 51:662-668

35. Li LX, Skorpen F, Egeberg K, Jorgensen IH, Grill V (2002) Induction of uncoupling protein $2 \mathrm{mRNA}$ in beta-cells is stimulated by oxidation of fatty acids but not by nutrient oversupply. Endocrinology 143:1371-1377

36. Puigserver $\mathrm{P}, \mathrm{Wu} \mathrm{Z}$, Park CW, Graves R, Wright M, Spiegelman BM (1998) A cold-inducible coactivator of nuclear receptors linked to adaptive thermogenesis. Cell 92:829-839

37. Cassard-Doulcier AM, Gelly C, Fox N et al. (1993) Tissuespecific and beta-adrenergic regulation of the mitochondrial uncoupling protein gene: control by cis-acting elements in the 5'-flanking region. Mol Endocrinol 7:497-506

38. Silva JE, Rabelo R (1997) Regulation of the uncoupling protein gene expression. Eur J Endocrinol 136:251-264

39. Armstrong MB, Towle HC (2001) Polyunsaturated fatty acids stimulate hepatic UCP-2 expression via a PPARalphamediated pathway. Am J Physiol Endocrinol Metab 281:E1197-E1204

40. Nakatani T, Tsuboyama-Kasaoka N, Takahashi M, Miura S, Ezaki O (2002) Mechanism for peroxisome proliferatoractivated receptor-alpha activator-induced up-regulation of UCP-2 mRNA in rodent hepatocytes. J Biol Chem 277:9562-9569

41. Lopez-Solache I, Marie V, Camirand A, Silva JE (2002) Regulation of uncoupling protein-2 mRNA in L6 myotubules: II: thyroid hormone amplifies stimulation of uncoupling protein-2 gene by thiazolidinediones and other peroxisome proliferator-activated receptor ligands in L6 myotubules: evidence for a priming effect. Endocrine 19:209217

42. Ahren B (2000) Autonomic regulation of islet hormone secretion-implications for health and disease. Diabetologia 43:393-410 